\title{
食生活をめぐる諸問題 \\ Various Matters of Food System
}

木 村 進

Kimura Susum

（（社）日本パン技術研究所）

\section{1. 我が国の食生活の変遷}

ここ, 約 20 年来, 我が国は「豊かな食生活」および「長 寿社会」を譡歌し今日に至っている。この豊かな食生活 は表 1,2 に示すように第二次大戦後の「飢餓の食生活」 から「途上国型食生活」を経て「欧米追随の食生活」と なり, その後, 昭和 40 年代には食生活の内容の充実に伴 い, 栄養バランスの良否の指標である PFC 熱量比率は FAO などが推奖する理想型に達した（表 3 参照)．昭和 45年頃には“成熟の食生活”と表現されるようになり,
昭和55年の農政審議会においては「日本型食生活の定着」 が提唱された．さらに，昭和 60 年前後から “飽食の食生 活”と表現されるようになり今日に至っている。すなわ ち, 戦後わずか 20 数年の間に飢餓の食生活から理想的な 内容の食生活に変遷したといら，世界に類例を見ないド ラスティックな変遷をとげた.

その第一の要因は, 我が国の産業, 経済が急速かつ着 実な発展をとげ，同時に，為替レートの関係（円高）か ら, 諸外国から安価に食料およびェネルギー(化石燃料), 鉱工業原料の輸入が可能になったことなどである.

表 1 食生活の 5 つのステップ

一第二次大戦後からの栄養·食生活·志向等の変遷一

\begin{tabular}{c|l|c}
\hline 年次 & \multicolumn{1}{|c|}{ 食 料 事 情 等 } & 食 生 活 の 内 容 等 \\
\hline 昭和 20 & 食料の極度の不足 & 慨餓状態（昭和 21 年の巷給熱量 $1,448 \mathrm{kcal} /$ 人 $/$ 日）
\end{tabular}

【東京, 大阪で毎月数十人の餓死者が出た．11月には東京日比谷公園で餓死対策国民大会が開かれた】

\begin{tabular}{|c|c|c|}
\hline$\downarrow$ & $\begin{array}{l}\text { アメリカの食料援助 } \\
\text { 基本食料の増産, 未利用資源の利活用が進む }\end{array}$ & $\begin{array}{l}\text { 開発途上国型食生活 } \\
\text { (昭和 } 26 \sim 29 \text { 年の平均供給熱量 } 1,934 \mathrm{kcal} / \text { 人 } / \text { 日 ) }\end{array}$ \\
\hline $\begin{array}{c}30 \\
\downarrow\end{array}$ & $\begin{array}{l}\text { 基本食料の充足達成（穀類供給量 } 154 \mathrm{~kg} / \text { 人/年うち米 } 111 ） \\
\text { 栄養の充足と改善が進む（供給熱量 } 2,217 \mathrm{kcal} / \text { 人 /日） }\end{array}$ & $\begin{array}{l}\text { 開発途上国型食生活から脱却 } \\
\text { インスタント食品の増加ら籣便性志向（1 期 })\end{array}$ \\
\hline$\downarrow$ & \multicolumn{2}{|c|}{ プラスチック包装・スーパーマーケットの台頭 } \\
\hline $\begin{array}{l}40 \\
\downarrow \\
\downarrow\end{array}$ & 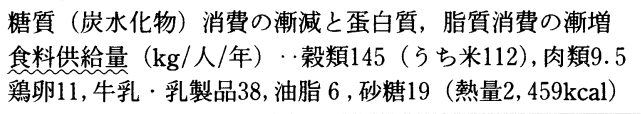 & $\begin{array}{l}\text { 欧米型食生活への追随. コールドチェーン勧告 } \\
\text { 食生活の合理化 } \leftrightharpoons \text { 簡便性志向（2期） } \\
\text { 加工食品の急増（生産量約 } 3,000 \text { 万 } \mathrm{t} \text { ↔昭和 } 45 \text { 年） }\end{array}$ \\
\hline $\begin{array}{c}45 \\
\downarrow \\
\downarrow \\
55 \\
\downarrow\end{array}$ & 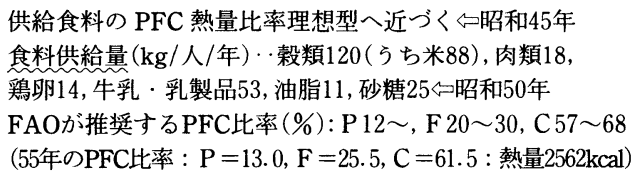 & $\begin{array}{l}\text { 成熟の食生活の段階へ } \\
\text { 加工食品の生産增加と広域流通が進行 } \\
\text { 加工食品の多品種・少量生産の傾向が増大 } \\
\text { 『日本型食生活の定着』の提言（農政審議会 } 55 \text { 年） } \\
\text { 志向 } \Rightarrow \text { 多様华·高級华. ニールドチェーソの整備 }\end{array}$ \\
\hline $\begin{array}{c}60 \\
\text { 平成元年 } \\
\downarrow \\
\text { 現在 }\end{array}$ & 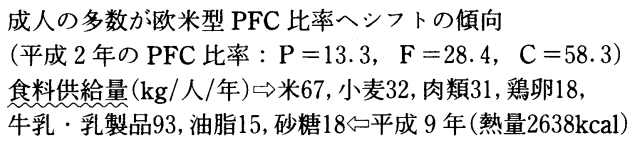 & 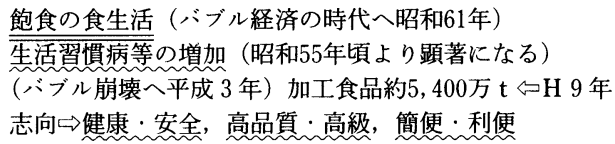 \\
\hline
\end{tabular}

【食品加工技術, 食品包装材料·技術及び物流技術の進歩‥コールドチェーンの整備…食関連耐久消費財の普及…自動販売機の普及】

本稿は第19回大会の主題講演を緾めたものである.

（木村 進 1999年 3 月改定） 
表 2 長期的にみた純食料供給構造の変化

（1 人 $\cdot 1$ 年当たり供給純食料 単位 : $\mathrm{kg}$ )

\begin{tabular}{|c|c|c|c|c|c|c|c|c|c|c|c|}
\hline & 昭和 5 年 & 10 & 14 & 21 & 25 & 30 & 35 & 45 & 55 & 平成 2 年 & 9 \\
\hline 穀 類 & 159.1 & 152.6 & 163.5 & 117.5 & 162.1 & 154.3 & 149.6 & 128.2 & 112.9 & 103.8 & 100.6 \\
\hline らち 米 & 132.9 & 126.3 & 138.7 & 92.7 & 110.1 & 110.7 & 114.9 & 95.1 & 78.9 & 70.0 & 66.7 \\
\hline らち小麦 & 9.5 & 10.6 & 9.5 & 14.6 & 26.6 & 25.1 & 25.8 & 30.8 & 32.2 & 31.7 & 32.4 \\
\hline いむ類 & 29.6 & 28.1 & 23.7 & 60.6 & 49.6 & 43.6 & 30.5 & 16.1 & 17.3 & 20.6 & 21.3 \\
\hline でん粉 & 0.7 & 1.1 & 2.6 & 0.4 & 1.1 & 4.6 & 6.5 & 8.1 & 11.6 & 15.9 & 16.6 \\
\hline 豆 類 & 5.5 & 5.5 & 4.7 & 1.1 & 1.1 & 9.4 & 10.2 & 10.1 & 8.5 & 9.3 & 9.2 \\
\hline 菜 & 74.8 & 74.8 & 72.6 & 51.1 & 63.5 & 82.3 & 99.7 & 114.2 & 110.3 & 107.2 & 101.7 \\
\hline 実 & 20.1 & 20.1 & 19.7 & 6.9 & 15.3 & 12.3 & 22.3 & 38.1 & 38.8 & 37.4 & 40.5 \\
\hline 類 & 1.9 & 1.9 & 2.4 & 0.9 & 2.3 & 3.2 & 5.0 & 13.4 & 22.5 & 28.5 & 30.7 \\
\hline 鶏 & 1.9 & 2.3 & 2.2 & 0.4 & 0.8 & 3.7 & 6.3 & 14.5 & 14.3 & 16.5 & 17.6 \\
\hline 牛乳·乳製品 & 2.7 & 3.2 & 3.8 & 1.6 & 5.3 & 12.1 & 22.3 & 50.1 & 62.1 & 83.2 & 93.2 \\
\hline 魚介類 & 13.5 & 13.9 & 12.8 & 9.5 & 14.5 & 26.3 & 27.8 & 31.6 & 34.8 & 37.1 & 36.0 \\
\hline 砂 糖 類 & 13.5 & 13.1 & 11.3 & 0.7 & 2.9 & 12.3 & 15.1 & 26.9 & 23.3 & 21.0 & 18.4 \\
\hline 油脂 類 & 0.8 & 0.8 & 1.4 & 0.1 & 0.8 & 2.7 & 4.3 & 9.0 & 12.6 & 14.2 & 15.0 \\
\hline 噌 & 10.7 & 10.9 & 7.2 & 7.1 & 6.7 & 9.9 & 8.8 & 7.3 & 6.0 & - & - \\
\hline 酱 & 14.3 & 13.8 & 14.2 & 7.2 & 11.6 & 14.3 & 13.7 & 11.8 & 11.0 & - & - \\
\hline 熱量kcal/日 & $2,256^{11}$ & & & 1,448 & 1,945 & 2,217 & 2,289 & 2,529 & 2,562 & 2,634 & 2,638 \\
\hline
\end{tabular}

資料：経済安定本部「戦前戦後の食糧事情一昭和 $5 \sim 14$ 年および $21 \sim 25$ 年食糧バランスンート」. 供給熱量の 1 ) は昭和 $6 \sim 10$ 年の平 均である. 農林水産省「食料需給表」ただし $26 \sim 29$ 年は食料需給表旧推計による. 昭和 47 年以降は沖縄の本土復帰に伴い沖縄県を含 んだ数値である. したがって, 時系列的には, 昭和 $5 \sim 25$ 年, 昭和 $26 \sim 29$ 年, 昭和 30 年以降に区分され, 数值は必ずしも連続しない,

（食品産業センター「食品産業統計年報」昭和 62 年版及び平成 9 年度食料需給表より作成 1999.9 木村 進)

表 3 日本の PFC 熱量比率の推移

単位 $(\%)$

\begin{tabular}{l|c|c|c}
\hline & 蛋白質 $(\mathrm{P})$ & 脂質 $(\mathrm{F})$ & 炭水化物 $(\mathrm{C})$ \\
\hline 1955 (昭30) & 11.3 & 8.8 & 79.9 \\
1960 (昭35) & 12.2 & 11.4 & 76.4 \\
1965 (昭40) & 12.2 & 16.2 & 71.6 \\
1970 (昭45) & 12.2 & 20.0 & 67.6 \\
1975 (昭50) & 12.7 & 22.8 & 64.4 \\
1980 (昭55) & 13.0 & 25.5 & 61.5 \\
1985 (昭60) & 13.1 & 27.3 & 59.7 \\
1990 (平 2) & 13.3 & 28.4 & 58.3 \\
1995 (平 7) & 13.7 & 29.4 & 56.9 \\
1996 (平 8) & 13.6 & 29.7 & 56.7 \\
1997 (平9) & 13.5 & 30.0 & 56.6 \\
\hline
\end{tabular}

資料：農林水産省「食料需給表」(供給熱量の PFC 熱量比率)

注 : 昭和 39 年以前は. 科学技術庁刊行「三訂日本栄養成分表」 40 年以降は, 「四訂日本食品栄責成分表」を適用した。

参考 : PFC 熱量比率とは総熱量（総カロリー）に占めるPFCのカロリー 比率.

第二の要因は, 戦前から蓄積されていた科学技術を基 盤とした食品科学. 工学などの進歩により, 食品貯蔵. 加工技術および装置，食品包装技術および資材，装置な ぞの改善, 開発が推進されてきたことである.つまり,
内外で開発された食品貯蔵・加工・流通関連の新技術 装置・資材などを的確に導入し活用してきたからであ る. したがって, 生鮮食品, 加工食品ともに品質を保持 し, かつ, 安定的に広域流通が可能となったことである. また, 電気冷蔵冷凍庫, 電子レンジなどの食に関連する 耐久消費財, 飲食料品の自動販売機などの普及などによ り，豊かで快適な食生活が営めるようになったことであ る.

各家庭における食料費支出の構成比の推移を総務庁 「家計調查」でみると, 表 4 のよ5に昭和 40 年では穀物 $19.3 \%$, 生鮮食品 $33.2 \%$, 加工食品 $47.5 \%$ であったが, 平成10年にはそれぞれ $5.6 \% ， 32.4 \% ， 62.0 \%$ 変化し ている.このことは，すでに数年前から各家庭の「台所」 の約 6 割が食品加工工場に移行したことを物語ってい る.

これらのことから言い得ることは，今日のわれわれの 食生活において食品加工および食品流通のはたす役割は 極めて大きいことである．換言すれば，高度の食品加工 技術，包装技術，流通技術の総合によって今日の「豊か な食生活」が支えられているわけである.ささらに表現を 換えて言らなれば, 食品産業（後述）の社会的使命と責 
表 4 食料支出の構成

\begin{tabular}{c|c|c|c|c||c}
\hline \multicolumn{1}{|c|}{ 年 度 } & 穀物 & 生鮮食品 & 加工食品 & 外食 & $\begin{array}{c}\text { エンゲル } \\
\text { 係数 }\end{array}$ \\
\hline 1965 (S 40) & $\begin{array}{c}17.9 \\
(19.3)\end{array}$ & $\begin{array}{c}30.8 \\
(33.2)\end{array}$ & $\begin{array}{c}44.0 \\
(47.5)\end{array}$ & 7.2 & 38.1 \\
\hline 1970 (S 45) & $\begin{array}{c}12.3 \\
(13.7)\end{array}$ & $\begin{array}{c}33.2 \\
(36.9)\end{array}$ & $\begin{array}{c}44.6 \\
(49.5)\end{array}$ & 9.9 & 34.1 \\
\hline 1975 (S 50) & $\begin{array}{c}8.8 \\
(9.9)\end{array}$ & $\begin{array}{c}33.3 \\
(37.6)\end{array}$ & $\begin{array}{c}46.6 \\
(52.5)\end{array}$ & 11.3 & 32.0 \\
\hline 1980 (S 55) & $\begin{array}{c}8.2 \\
(9.5)\end{array}$ & $\begin{array}{c}31.6 \\
(36.6)\end{array}$ & $\begin{array}{c}46.4 \\
(53.8)\end{array}$ & 13.8 & 29.0 \\
\hline 1985 (S 60) & $\begin{array}{c}8.0 \\
(9.4)\end{array}$ & $\begin{array}{c}30.1 \\
(35.5)\end{array}$ & $\begin{array}{c}46.8 \\
(55.1)\end{array}$ & 15.1 & 27.0 \\
\hline 1990 (H 2) & $\begin{array}{c}6.3 \\
(7.5)\end{array}$ & $\begin{array}{c}28.8 \\
(34.5)\end{array}$ & $\begin{array}{c}48.5 \\
(58.0)\end{array}$ & 16.4 & 25.4 \\
\hline 1995 (H 7) & $\begin{array}{c}5.4 \\
(6.5)\end{array}$ & $\begin{array}{c}27.3 \\
(32.9)\end{array}$ & $\begin{array}{c}50.1 \\
(60.5)\end{array}$ & 17.2 & 23.7 \\
\hline 1997 (H 9) & $\begin{array}{c}4.8 \\
(5.8)\end{array}$ & $\begin{array}{c}26.5 \\
(32.2)\end{array}$ & $\begin{array}{c}50.9 \\
(61.9)\end{array}$ & 17.8 & 23.5 \\
\hline 1998 (H 10) & $\begin{array}{c}4.7 \\
(5.6)\end{array}$ & $\begin{array}{c}26.7 \\
(32.4)\end{array}$ & $\begin{array}{c}51.1 \\
(62.0)\end{array}$ & 17.5 & 23.8 \\
\hline
\end{tabular}

資料：総務庁「家計調查」(全国全世帯）(品目分類）

注：1.「款物」とは粒状のまま最終消費される穀物及び豆類をいい,「加 工食品」とは穀物及び生鮮食品以外の食品をいう．

2.（）内は外食を除いた割合である.
任は極めて重いといえよう.

一方，「食」をめぐる昨今のキーワードは“健康·安 全·衛生”, “高品質·高級”, “簡便·利便”, 飽食, 食 料自給率, 残飯の量, 賞味期限, 生活習慣病, 病原微生 物中毒, HACCP, PL 法, 有機栽培農産物（オーガ二 ック), 遺伝子組換え食品, 容器包装リサイクル法, ゴ ミ焼却, ダイオキシン, 環境ホルモン, 地球温暖化等々 と広範多岐にわたっている。

\section{2. 食生活をめぐる今日的, 将来的問題}

今日の豊かな食生活を営むために必要とする食料（間 接の食料である飼料を含む）の量は，農林水産省「食料 需給表」および大蔵省「貿易統計」によれば, 国内およ び輸入農畜水産物ともに約 6,000 万トンであり，合計約 1 億 2,000 万トンである. これら大量の食料を貯蔵, 保 管, 加工, 輸送, 販売し消費者に提供している産業が食 品産業（食品工業, 外食産業, 食品関連流通業の三者の 総称）である．換言すれば，今日の豊かな食生活を支え ているのが食品産業といえよう，そこで，はじめに食品 産業の概要を述べておく.

食品工業の出荷額は表 5 のように平成 7 年度には 35 兆 円産業となったが，その後は横ばいで，平成 9 年度には 35兆4,433億円となっている. 外食産業の販売額は昭和 50 年度には 8 兆6,000億円であったが，その後急成長を

表 5 食品工業の業種別出荷額の推移

(単位 : 100万円)

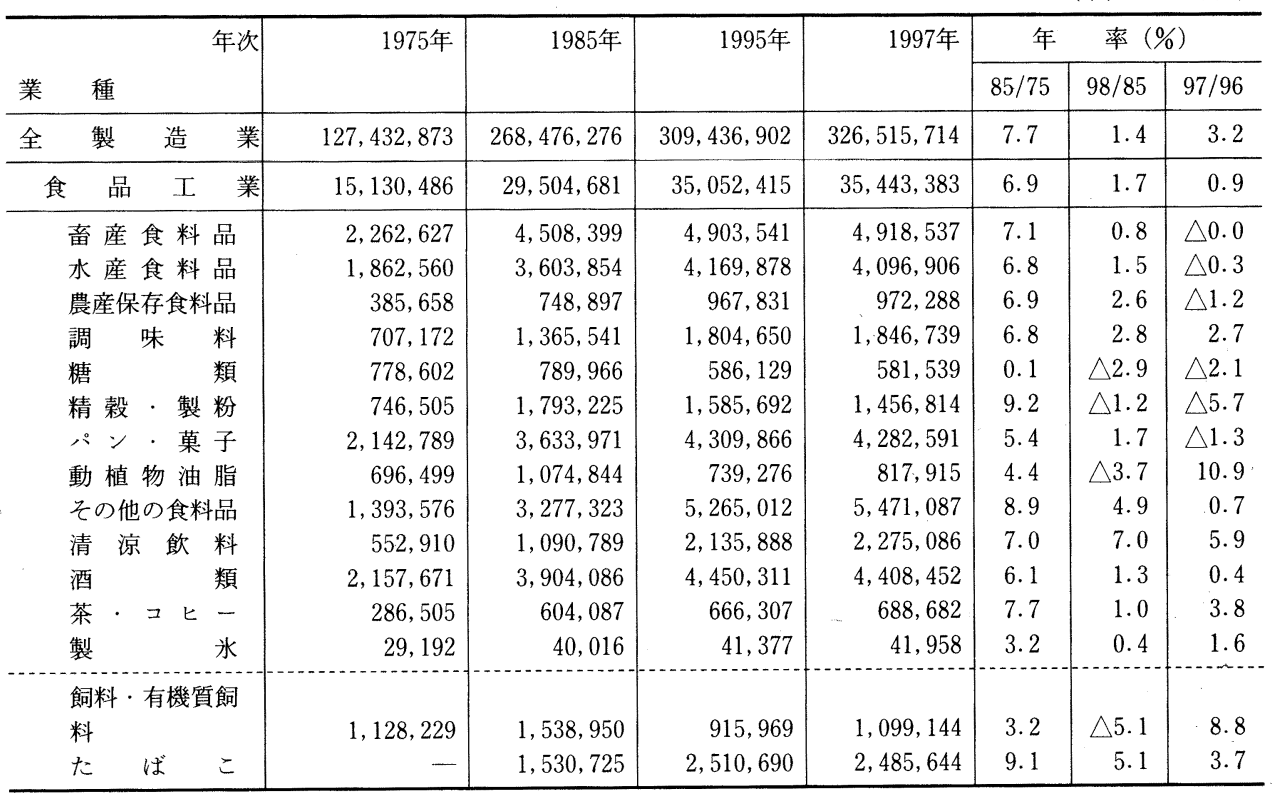

資料: 通産省「工業統計表（産業編）」(食品産業センター発行：『食品産業の主要指標』1999.8より転記) 
(単位 : \%)

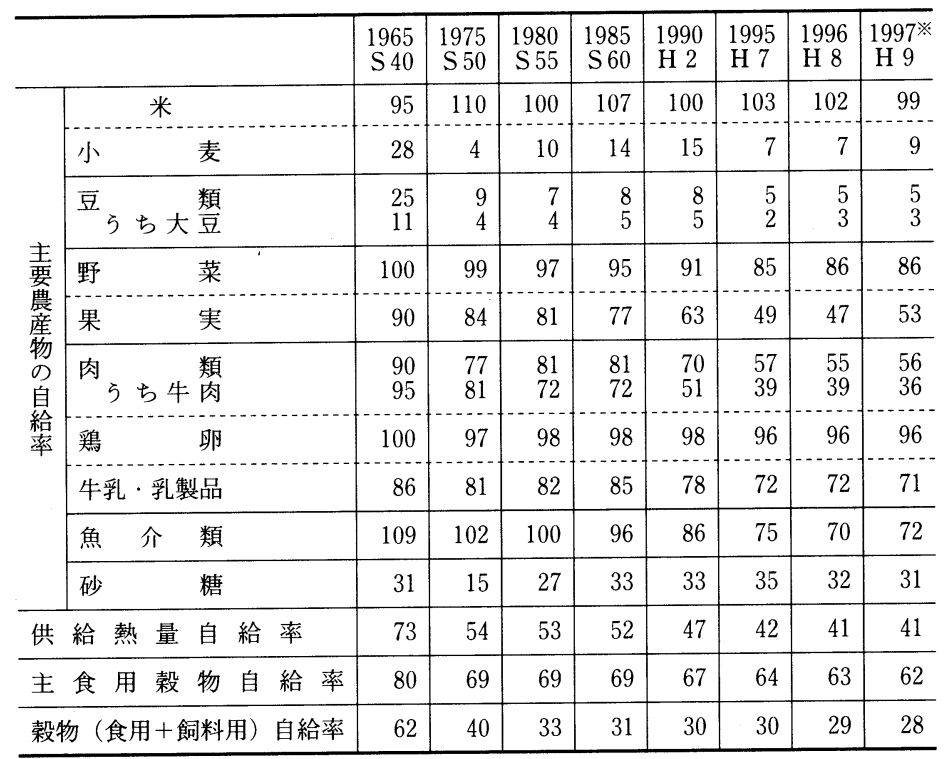

資料：農林水産省「食料需給表」 $1997 *$ は概算

注：1）品目別自給率，主食用穀物自給率及び穀物自給率の算出は次式による. 自給率 $=$ 国内生産量 $/$ 国内消費仕向量 $\times 100$ (重量ベース）

ただし, 本式により求めた米の自給率が100\%を下回る1980年度（87\%）及び1988年度 $(94$ \%)については，米の需給事情を考虑して $100 \%$ とした。

2 ) 供給熱量自給率の算出は次式による.

自給率 $=$ 国産供給熱量 $/$ 国内総供給熱量 $\times 100$ (熱量ベース)

ただし，畜産物については，資料自給率を考慮して算出した。

続け昭和 60 年度 19 兆 4,000 億円, 平成 6 年度約 28 兆円, 平成 8 年度約 29 兆円に達した，平成 10 年度には 29 兆弱の 産業となっている.すなわち, 食品産業, 外食産業とも に食生活が成熟の段階（一部は飽食）に達したこと， ハ ブル経済の崩壊の影響を受けていることから成長は鈍化 していることがわかる，食品関連流通業は約 10 兆円の規 模である.したがって, 食品産業への最終消費者支払い 額は, 低く見積もっても80兆円以上と推定されている.

このよらに, 食品産業は巨大産業で全産業中 3 位の産 業であるが，企業規模からみると中小企業的性格が極め て強い，例えば，食品工業に打いては，中小企業のシェ アは事業所数で $99 \%$ 以上, 就業者数で $84 \%$, 出荷額で 80 \%である．食品産業を支える就業者の合計は約 740 万人 であり，その内訳は，食品製造業 130 万人，外食産業 260 万人, 食品関連流通業 350 万人である.

以上, 今日の食生活を思考する場合, 食品の貯蔵·加 工・流通などが前提となるので, 敢えて本論に入る前に 食生活を支える産業，すなわち，食品産業の概要につい て述べた.
以下，本稿では食生活の現状および将来を考察するた め,「食」をめぐる諸問題を12の項目に要約して記述す る.

\section{（1）食料の自給率}

我が国の食料自給率の推移は表 6 のごとくであり，平 成 9 年のカロリー換算自給率は $41 \%$ である.諸外国では, アメリカ $130 \sim 140 \%$ ，フランス $130 \%$ 前後，西ドイッ 90 \%以上，イギリス約 $80 \%$ である。このよらに, 我が国は 先進国のらちで最も食料資源の乏しい国である.ささに 輸入農畜産物の生産（栽培）に必要な耕地面積から自給 率を試算すると約 $30 \%$ 以下である. すなわち，今日の豊 かな食生活の 7 割以上は海外の食·飼料輸出国に依存し ていることを意味している.

平成 7 年の農政審議会においては, 2010年のカロリー 換算自給率の見通しを $44 \sim 46 \%$ とている．本年制定さ れた「食料・農業・農村基本法」においても自給率の向 上をらたっているが，具体的な数值は示されていない.

以上のよらな現状と予測から見るならば,近い将来も, われわれの食料および食品加工原料の大半は現在と同様 
表 7 食料輸入金額の推移

\begin{tabular}{|c|c|c|c|c|c|c|c|c|c|c|c|c|}
\hline 年 & & 8 & 89 & 1990 & 91 & 992 & 1993 & 1994 & 995 & 996 & 1997 & 1998 \\
\hline 金額（億 \$） & & & & & & & & & & 015 & & 420 \\
\hline 前年比 & - & 30.6 & 5. & 0 & 7. & 8.5 & 5. & 17. & 9 & 0.8 & 8. & 11. \\
\hline
\end{tabular}

出所 : 大藏省貿易統計

表 8 主要輸入食料品・数量および金額（1998年）

\begin{tabular}{|c|c|c|c|c|c|}
\hline 品 & $\left(\begin{array}{l}\text { 数量 } \\
\text { t })\end{array}\right.$ & $\begin{array}{c}\text { 金額 } \\
\text { (億\$) }\end{array}$ & 品 & $\left(\begin{array}{l}\text { 数量 } \\
(\mathrm{t})\end{array}\right.$ & $\begin{array}{c}\text { 金額 } \\
(\text { 億 } \$ \text { ) }\end{array}$ \\
\hline 穀類及び調製品 & 28,446 & 51.13 & 野菜及び調製品 & $\cdots$ & 29.46 \\
\hline らち小麦 & 5,758 & 10.94 & らち生鮮·冷蔵 & 739 & 9.35 \\
\hline "大麦, はだか麦 & 1,470 & 2.15 & （かばちゃ） & 129 & .93 \\
\hline "トウモロコシ & 16,047 & 20.92 & （まつたけ） & 3 & 1.23 \\
\hline " グレンソルガム & 2,686 & 3.24 & " 冷凍野菜 & 653 & 8.03 \\
\hline 肉類及び調製品 & 2,097 & 69.06 & " 野菜加工 & $\ldots$ & 6.04 \\
\hline らち豚 & 517 & 22.03 & " 乾燥野菜 & 52 & 2.51 \\
\hline " 牛 & 666 & 23.24 & 糖類及び調製品·蜂蜜 & 1,929 & 5.89 \\
\hline " 鷄 & 497 & 9.03 & らち粗 糖 & 1,549 & 3.99 \\
\hline 魚介類及び調製品 & 2,694 & 126.08 & " 糖 & 214 & .24 \\
\hline らちまぐろ・かつお & 372 & 16.13 & " 乳 & 90 & .64 \\
\hline "ささけ及びます & 227 & 9.33 & " 砂糖菓子 & 11 & 42 \\
\hline$"$ え & 251 & 27.68 & コーヒー・ココア・茶 & & \\
\hline "か & 123 & 7.35 & ·香辛料類 & 654 & 19.65 \\
\hline "”らなぎ（加工） & 52 & 6.44 & 油糧種子（除く落花生） & 7,329 & 23.29 \\
\hline " らなぎ（活鰻） & 13 & 1.67 & らち大 & 4,751 & 14.32 \\
\hline " たら冷凍すり身 & 126 & 2.34 & " 菜 & 2,078 & 6.76 \\
\hline 果実類及び調製品 & $\cdots$ & 22.43 & 飲 & 1,268 & 25.70 \\
\hline らちバナナ & 885 & 4.37 & らちビール & 81 & .66 \\
\hline " グレープフルーツ & 284 & 2.56 & "ワイン & 325 & 12.88 \\
\hline " オレンジ & 150 & 1.33 & " ウイスキー & 49 & 3.61 \\
\hline$" レ モ ン$ & 86 & 1.25 & " ブランデー & 14 & 2.90 \\
\hline " 果実缶詰 & 193 & 2.19 & " 非アルコール飲料 & 106 & .71 \\
\hline " 果実飲料 & 180 & 3.52 & "ミミネラルウォター & 159 & .80 \\
\hline ナッッ及び調製品 & 191 & 4.90 & 調製飼料 & 6,151 & 20.48 \\
\hline
\end{tabular}

資料：大藏省貿易統計 （左の資料から主要食料等を抜粋し作表 1999. 6 作表 木村 進）

〔1998年総輸入額2793億ドル，ちち食料輸入額：420億ドル（11.6\%減），5兆1639億円（3.5\%減）…不況と円安〕

に，農畜産物輸出国に依存せざるを得ないであろら。し たがって, 将来の食料は輸出国の天候, 農産物の作柄, 農政拈よび外交により“価格”，“品質”，“量”は大きく 変動することを覚悟しなければならない.すなわち, 将 来の食料供給は多くの不安定要因を包含しているといえ よう.

\section{（2）食・飼料の輸入}

我が国の食料輸入は, 成熟の食生活の段階に達した昭 和50年の輸入金額は100億ドル，昭和61年は208億ドル， その後, 食料自給率の低下と飽食を反映して昭和 63 年に は309億ドル, 平成 8 年には519億ドルと増加した. 平成 9 年からは“不況”之“円安”を反映して輸入金額は減 少し, 平成 10 には 420 億ドルとなった. 輸入食料の内容 の特徵は魚介類と肉類の輸入金額（195億ドル）が全食
料輸入金額の約半数 $(47 \%)$ であり，飽食，高級化の傾 向が数值として明らかに示されている(表 7,8 参照).

一方, 輸入食料に関連する問題として, 輸入食料の安 全性が問題となっている. 例えば, 農薬の残留（ポスト ハーベスト農薬の残留を含む)，家畜飼育時の抗生物質 およびホルモン剂の残留, 食品添加物以外の添加物の添 加, 各種異物の混入, アスペルギルス・フラーブス, コ レラ菌, サルモネラ菌, リステリア菌などによる污染な どである. これらの対策として, 検査・検出の迅速化, 適正化, 省力化に関する技術および計測機器の開発が必 要であり，また，検査体制の整備が必要である.

\section{（3）国民の栄養水準（状態）}

国民 1 人 1 日当たりの供給熱量は $2,638 \mathrm{kcal}$ (らちで んぷん質 $1,202 \mathrm{kcal}$ )，たんぱく質は $88.8 \mathrm{~g}$ （らち動物 
性 $47,2 \mathrm{~g}$ ), 脂質 $87.8 \mathrm{~g}$ であり, $\mathrm{PFC}$ 熱量比率は $\mathrm{P}=$ $13.5: \mathrm{F}=30.0: \mathrm{C}=56.6$ である（農水省「食料需給表」 平成 9 年度. 表 $2 ， 3$ 参照). これらの数值から見れば, 栄養水準は極めて好ましい段階にあるといえよう。しか し，厚生省の「国民栄養調査」によれば，成人はもちろ ん児童までも生活習慣病の増加が指摘されている.すな わち, 供給 PFC 值の平均值からは栄養バランスは良好 と言い得るが，食料摂取状況から見ると, 部分的に栄養 バランスが欧米型ヘシフトし，生活習慣病の増加の要因 となっている. 一説によると糖尿病患者は顕在, 潜在を 含め 1,300 万人以上ともいわれている. そこで, 厚生省 では「栄養所要量」の第 6 次改定を行うとともに「食事 摂取基準」を策定し生活習慣病の一次予防に努めている.

また,一般消費者の段階では各種のダイェットフード,
いわゆる「健康食品」が一部でブームともなっており, 「特定保健用食品」（機能性食品）が食品·医薬品業界 でブームとなっている.また, 数年前から有機栽培農産 物（いわゆるオーガニック食品）が消費者の関心を呼ん でいる。

\section{（4）消費者の「食」への志向}

国民の栄養状態は上述のように極めて好ましい段階に あり，また，表 4 に示されているェンゲル係数からみて も, 豊かな食生活が続けられている. しかし, 過去にさ かのぼる食品添加物問題（例えば，AF2，チクロほか), チェルノブイリ原発事故による食品の放射能污染問題, 上述(2)に述べた問題輸入食品および昨今の飽食傾向を反 映しての生活習慣病の増加等々の要因から, 消費者の食 品に対する志向の第一は “健康 · 安全” 志向であり,

表 9 牛乳・乳製品の生産量の推移

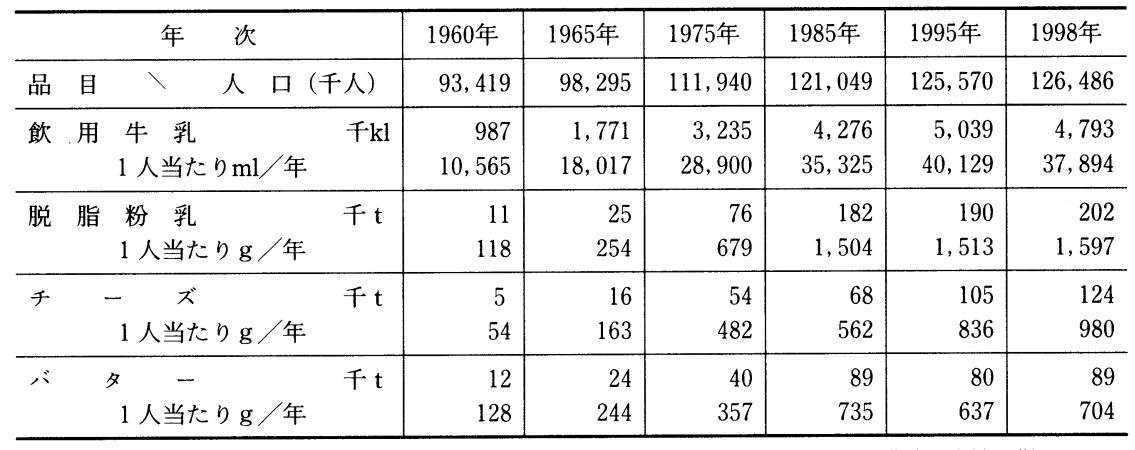

資料：(时)食品産業センター「食品産業統計年報」昭和53年及び平成11年版より拔粋（1999．10作表 木村 進)

表10 食肉加工品の生産量の推移

\begin{tabular}{|c|c|c|c|c|c|c|}
\hline 次 & 1960年 & 1965年 & 1975年 & 1985年 & 1995年 & 1998年 \\
\hline 品目〉人口（千人） & 93,419 & 98,295 & 111,940 & 121,049 & 125,570 & 126,486 \\
\hline $\begin{array}{c}\text { 肉加工品 } \quad \text { 計 } \\
1 \text { 人当たり } \mathrm{g} / \text { 年 }\end{array}$ & $\cdots$ & $\begin{array}{r}130 \\
1,323\end{array}$ & $\begin{array}{r}299 \\
2,671\end{array}$ & $\begin{array}{r}466 \\
3,850\end{array}$ & $\begin{array}{r}554 \\
4,412\end{array}$ & $\begin{array}{r}527 \\
4,166\end{array}$ \\
\hline $\begin{array}{l}\text { 5ち 公類 千 } \\
1 \text { 人当たり } \mathrm{g} / \text { 年 }\end{array}$ & $\cdots$ & $\begin{array}{c}7 \\
71\end{array}$ & & $\begin{array}{l}105 \\
867\end{array}$ & $\begin{array}{r}131 \\
1,043\end{array}$ & $\begin{array}{l}124 \\
980\end{array}$ \\
\hline $\begin{aligned} \text { らち プレス 類 千 } \mathrm{t} \\
1 \text { 人当たり } \mathrm{g} / \text { 年 }\end{aligned}$ & $\begin{array}{l}\cdots \\
\cdots\end{array}$ & $\begin{array}{r}61 \\
621\end{array}$ & $\begin{array}{l}102 \\
911\end{array}$ & $\begin{array}{r}79 \\
653\end{array}$ & $\begin{array}{r}36 \\
287\end{array}$ & $\begin{array}{r}29 \\
229\end{array}$ \\
\hline $\begin{array}{l}\text { 万ち ソーセージ類 千 } \\
1 \text { 人当たり } \mathrm{g} / \text { 年 }\end{array}$ & $\begin{array}{l}\cdots \\
\cdots\end{array}$ & $\begin{array}{r}52 \\
529\end{array}$ & $\begin{array}{r}143 \\
1,277\end{array}$ & $\begin{array}{r}228 \\
1,884\end{array}$ & $\begin{array}{r}310 \\
2,469\end{array}$ & $\begin{array}{r}297 \\
2,348\end{array}$ \\
\hline $\begin{array}{l}\text { らち ベーュン類 } \\
1 \text { 人当たり } \mathrm{g} / \text { 年 }\end{array}$ & $\cdots$ & $\begin{array}{r}3 \\
31\end{array}$ & $\begin{array}{r}17 \\
152\end{array}$ & $\begin{array}{r}54 \\
446\end{array}$ & $\begin{array}{r}77 \\
613\end{array}$ & $\begin{array}{r}78 \\
617\end{array}$ \\
\hline $\begin{array}{c}\text { 水産ねり製品 計 千 } \mathrm{t} \\
1 \text { 人当たり } \mathrm{g} / \text { 年 }\end{array}$ & $\begin{array}{r}509 \\
5,449\end{array}$ & $\begin{array}{r}797 \\
8,108\end{array}$ & $\begin{array}{r}1,155 \\
10,318\end{array}$ & $\begin{array}{r}984 \\
8,129\end{array}$ & $\begin{array}{r}801 \\
6,379\end{array}$ & $\begin{array}{r}773 \\
6,111\end{array}$ \\
\hline $\begin{array}{c}\text { らち魚肉ハム・ソーセージ千 } \mathrm{t} \\
1 \text { 人当たり } \mathrm{g} / \text { 年 }\end{array}$ & $\begin{array}{r}101 \\
1,081\end{array}$ & $\begin{array}{r}188 \\
1,913\end{array}$ & $\begin{array}{r}121 \\
1,081\end{array}$ & $\begin{array}{r}92 \\
760\end{array}$ & $\begin{array}{r}66 \\
526\end{array}$ & $\begin{array}{r}65 \\
514\end{array}$ \\
\hline
\end{tabular}

資料：(財食品産業センター「食品産業統計年報」昭和 53 年版及び平成 11 年度版より拔粋 
表11 コンビニェンス食品等の生産量の推移

\begin{tabular}{|c|c|c|c|c|c|c|}
\hline 年 & 1960年 & 1965年 & 1975年 & 1985年 & 1995年 & 1998年 \\
\hline 品目〉人口（千人） & 93,419 & 98,295 & 111,940 & 121,049 & 125,570 & 126,486 \\
\hline $\begin{array}{c}\text { 冷 凍 食 品 } \\
1 \text { 人当たり } \mathrm{g} / \text { 年 }\end{array}$ & $\begin{array}{c}5 \\
53\end{array}$ & $\begin{array}{r}26 \\
265\end{array}$ & $\begin{array}{r}355 \\
3,171\end{array}$ & $\begin{array}{r}778 \\
6,427\end{array}$ & $\begin{array}{r}1,365 \\
10,870\end{array}$ & $\begin{array}{r}1,489 \\
11,772\end{array}$ \\
\hline $\begin{array}{l}\text { らち調理食品 } \\
1 \text { 人当たり } \mathrm{g} / \text { 年 } \\
\text { 調理食品の割合 }(\%)\end{array}$ & $\begin{array}{c}3 \\
32 \\
54\end{array}$ & $\begin{array}{c}9 \\
92 \\
35\end{array}$ & $\begin{array}{r}241 \\
2,153 \\
68\end{array}$ & $\begin{array}{r}541 \\
4,469 \\
70\end{array}$ & $\begin{array}{r}1,101 \\
8,768 \\
66\end{array}$ & $\begin{array}{r}1,221 \\
9,653 \\
82\end{array}$ \\
\hline $\begin{array}{c}\text { 即席めん（使用小麦粉千 } \mathrm{t} \text { ） } \\
1 \text { 人当たり } \mathrm{g} / \text { 年 }\end{array}$ & $\cdots$ & $\begin{array}{r}185 \\
1,882\end{array}$ & $\begin{array}{r}335 \\
2,993\end{array}$ & $\begin{array}{r}316 \\
2,611\end{array}$ & $\begin{array}{r}314 \\
2,501\end{array}$ & $\begin{array}{r}318 \\
2,512\end{array}$ \\
\hline $\begin{array}{c}\text { 即 席 カレー } \\
1 \text { 人当たり } \mathrm{g} / \text { 年 }\end{array}$ & & $\begin{array}{r}33 \\
336\end{array}$ & $\begin{array}{r}70 \\
625\end{array}$ & $\begin{array}{r}86 \\
696\end{array}$ & $\begin{array}{r}96 \\
765\end{array}$ & $\cdots$ \\
\hline $\begin{array}{l}\text { レトルト食品 } \\
1 \text { 人当たり } \mathrm{g} / \text { 年 }\end{array}$ & & $\cdots$ & $\begin{array}{r}49 \\
438\end{array}$ & $\begin{array}{r}91 \\
752\end{array}$ & $\begin{array}{r}205 \\
1,633\end{array}$ & $\begin{array}{r}223 \\
1,763\end{array}$ \\
\hline 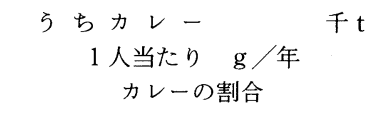 & $\cdots$ & $\begin{array}{l}\cdots \\
\cdots \\
\cdots\end{array}$ & $\begin{array}{r}38 \\
339 \\
78\end{array}$ & $\begin{array}{r}46 \\
380 \\
51\end{array}$ & $\begin{array}{r}87 \\
693 \\
42\end{array}$ & $\begin{array}{r}91 \\
719 \\
41\end{array}$ \\
\hline $\begin{array}{c}\text { インスタントコーヒー 千 } \mathrm{t} \\
1 \text { 人当たり } \mathrm{g} / \text { 年 }\end{array}$ & $\begin{array}{l}\cdots \\
\cdots\end{array}$ & $\begin{array}{c}7 \\
71\end{array}$ & $\begin{array}{r}21 \\
188\end{array}$ & $\begin{array}{r}33 \\
273\end{array}$ & $\begin{array}{r}32 \\
255\end{array}$ & $\begin{array}{r}31 \\
245\end{array}$ \\
\hline
\end{tabular}

次に, 家計の豊かさを反映して “高品質 ·高級”志向で あり, 食生活の洋風化, 合理化を反映し “簡便·利便” 志向である．すなわち，今日の消費者の志向はこの三つ に集約される. したがって, 食品の加工, 流通に当たっ ては，これらの要請に応えるための食品加工・包装技術 が駆使されている.

豊かで成熟の食生活の段階であること, 景気の低迷(バ ブル経済の崩壊）との影響から加工食品の多くは数年前 に生産のピークを示し, 以後は漸減している. しかし, 食事内容の洋風化・多様化および “簡便 ·利便”志向を 反映し, 表 9 〜1に示す加工食品の生産がいまだに微増 している.

\section{（5）食品企業（工場）の海外立地・進出}

国内労働力および貨金，国産加工原材料の価格などの 関係から, 食品企業が海外に工場を立地する傾向が強く, 製品の逆輸入が増加している. したがって, 一部では国 内の空洞化の危惧がもたれている.

海外生産比率は, すなわち, 各企業の国内売上高に占 める海外現地法人の売上高比率は, 食品工業では $2.4 \%$ であり，全製造業では7.4\%といわれている（平成 7 年 度). この数值からは食品企業の海外進出の率は低いが, 為替レートの変動の如何によっては海外進出が増加する ことも考えられる.

\section{(6) 為替レートの変動（乱高下）}

円／ドル相場は昭和60年頃までは 1 ドル 250 円台であ ったが，我が国の着実な経済成長に伴って, 昭和61年か ら200円台を割り170円台となった. その後, 乱高下を繰 り返しつつ徐々に円高が進み平成 5 年には110円台とな り, 平成 7 年には一時 80 円台を記録した. その後, 円安 傾向を続け, 昨今 (平成11年 1 月〜 9 月) では $120 \sim 105$ 円台となっている.このょうに国内外の経済情勢の変化 により, 円高·円安が交差し, 輸入食料（加工原料）の 価格の変動および化石燃料の価格変動があった。これら のことから, この十数年来, 製造コストが上下し, 加工 食品の值下げ，值上げとを繰り返してきた。すなわち， 我が国は経済大国とはいえ食料資源弱小国ゆえに, 輸入 する生鮮・加工食品の価格は将来とも為替レートの変動 の影響を受けざるを得ない。この問題は, 技術力では対 応し難い宿命的問題でもある.

\section{(7) 食品関連の法規・制度}

消費者への安全かつ高品質の食品の供給, 的確な情報 の提供などの消費者保護, 生鮮 · 加工食品の流通の円滑 化, 食料品の貿易摩擦の解消のための WTO 協定, CO DEX どの国際規格基準対応などから各種の食品関連 法規・制度が施行されている.

平成年代に設定，施行されている主な法規・制度を列 記すると, 平成 3 年 7 月から化学的合成品および天然添 加物すべてに関して全面的な表示が義務付けられた。平 
成 7 年 5 月に栄養改善法の改正により, 販売する食品に 何らかの栄養成分や熱量を表示する場合は, 主要栄養成 分についても併せて表示することが義務づけられ，「カ ルシウム強化」,「低カロリー」などを強調する場合, 厚 生省の基準の遵守が義務づけらた. 平成 7 年 4 月から 「製造年月日」表示から「期限表示」へ切り替えられ, 「消費期限」「賞味期限」または「品質保持期限」表示 が義務つけられた。平成 7 年 7 月から PL 制度（製造物 責任）が施行された. 平成 8 年 5 月にはHACCP シス テム（Hazard Analysis Critical Control Point 危害分 析重要管理点方式）の概念を導入した「総合衛生管理製 造過程」による製造・加工の承認制度が施行された. 11 年 7 月には従来の「農業基本法」に替わり「食料・農業

・農村基本法」が成立し, 農政において食料执よび食品 産業を従来以上に重視することが示された（農水省）.

厚生省では(3)で述べた「栄養所要量」の改定（第 6 次） と「食事摂取基準」の策定が 7 月行われた. 8 月には食 品の検查 ·認証, 表示制度に大きな变更が加えられ, 改 定 JAS 法が制定された（農水省）。むた，8月に「遺伝 子組換え食品」の表示の義務づけが決定され平成13年度 から実施されることとなった（農水省）. 厚生省では， 10月に「遺伝子組換光食品」の安全性確認登録の義務化 を制定した.

〔上記に関連し，製品の国際的な品質保証システムで ある ISO-9000s システムの認証を受ける食品工場も徐 々に増加している.」

\section{（8）食品加工技術, 包装技術の改善, 開発}

消費者のニーズに答え得る高品質の加工食品の製造, 新製品開発のための新素材開発に資するとともに, 製造 の場に拉ける省力化, 効率化, 省エネルギー化のため, 既存技術の改善とともに新技術の開発導入が推進されて きた. その導入の推移をみると, 効率的熱交換, 真空濃 縮, 凍結乾燥, 加圧加熱殺菌（特にレトルトパウチ食品 の殺菌), バイオリアクタ一利用, 凍結濃縮, 凍結粉砕, 膜利用, 加圧押出処理, 超臨界流体抽出, 通電加熱処理, 超高圧利用などである.

プラスチック包装材料は昭和 30 年前後から食品包装容 器として導入され始め, 「食品包装の第二の革命」をも たらし, 今日の食品包装には不可欠の包装材料となった. その後の改善・開発研究の成果により高遮断性, 高選択 透過性, 高耐熱性, 電子レンジ対応性, 抗菌性等, 各種 の機能性の高い包装材料が開発され実用化されるととも に, 真空包装, ガス置換包装, 脱酸素剤包装, 無菌充填 包装, 無菌化包装などの技術・装置が確立された.
同時に金属缶, ガラス瓶の軽量化と強度強化が進み, 製 品のシェルフライフの延長, 製品の物流（保管·輸送· 販売）の合理化が推進された. 下記の包装廃棄物問題に 関連し生分解性プラスチック等の新包装材料の開発が要 請されている.

\section{（9）食品包装容器の廃棄}

個装容器としての使命が終わったスチール缶, アルミ 缶, ガラス瓶, PETボトル, プラスチック容器, 紙容 器などはほとんどがワンウェーで廃棄される。これらの 廃棄物は, 容積ベースで一般廃棄物の約 $60 \%$ 占めてお り, その回収, リサイクル, 廃棄処理に多くの問題を包 含している.

包装容器の使用量の最も多い各種飲料（清涼飲料, 牛 乳. 乳飲料, アルュール飲料) の容器の年間使用の概数 を各種飲料の消費量 ( 3,080 万 $\mathrm{kl}$ 平成 10 年) から大胆な 試算（350ml缶に充填されたと仮定）を試みると年間約 880 億缶となる. 食品の物流に当たって使用される外装 材料の約 $95 \%$ は段ボール箱が採用され（二部, 発泡ポリ スチロース箱), $15 \mathrm{~kg}$ 用段ボール箱として換算すると年 間約 100 億箱以上が使用されている.

以上のように大量に廃棄される容器包装物を, リサイ クルにより資源の有効利用, 環境 - 景観の保全の見地か ら平成 7 年に「容器包装リサイクル法」が施行され, 平 成12年度からすべての容器包装にリサイクル法が施行さ れることになっている. 容器包装物のリサイクルは, 業 界の努力と消費者の協力によりリサイクルが順調に進 み, 平成10年にはアルミ缶の回収率は $74 \%$, スチール缶 の再資源化率は $83 \%$ ，ガラス瓶のカレット利用率は $74 \%$ となった。 このことは, 資源再利用の見地からみて好ま しい段階に達した.しかし, 飲料容器などのポイ捨ては, $3 \%$ 前後といわれており, 上記試算に当てはめると約 26 億缶がポイ捨てられたこととなり, 都市, 河川・海, 観 光地は包装ゴミ公害, 環境・景観污染の一因となってい る.

（10）残飯（厨芥類）および食品加工に伴う排水・廃棄物 家庭の台所および外食産業の的房から排出される残 飯, 欴芥類は或る調査によると 2,000 万トンといわれて いるが，農水省の平成 10 年の調査では 1,460 万トンであ り，「食料需給表」(食料供給量) および「国民栄養調査」 (食料摂取量) から試算すると約 1,500 万トンである. これらの量は供給粗食料の量から試算すると 16 2 $2 \%$ の 食料が残飯として廃棄されることであり，(1)で述べた我 が国の食料自給率から考えると大きな問題を包含してい る. 
食品加工に伴って排出される排水は，製品 1 トン当た り10〜30トンである. したがって，食品加工の場から排 出する排水は約15億トン以上と莫大な量と推定される. 排水による環境污染の防止の目的で水質污濁防止法が昭 和46年に制定され，監視が行き届き，規制が順守されて いるので，食品加工排水による環境污染・公害などの問 題が起こっていないのが現状である. 問題としては, 活 性污泥に上る排水処理に使用される電力は, 工場使用電 力の15３0\%を要し，また，その結果排出する余㮃污泥 の分離拈上び脱水, 廃棄に多くのエネルギーと経費を要 することである（污泥 1 トン当たり 1 ～万円）.

食品加工に伴って排出される加工残查（廃棄物）の量 は約1, 900万トン（らち80\%は余剩污泥）である. 加工 残渣は 1 トン当たり 5,000 10, 000 円の経費をかけ廃棄 処分されている.

残飯および加工排水・残渣は回収するならば，再利用 し得る有価成分を含有している．したがって，これらを 資源（バイオマス）としてとらえ，有価成分の回収変換
利用のための技術開発が必要である.

\section{(11) エネルギー消費}

食品加工工場で原料処理から加工, 包装, 出荷し小売 店を通じ (流通) て家庭での貯蔵および調理に至るまで に要するエネルギーを鶏肉について算出した数値は表 12 のごとくである．この表に見られるよらに, 冷蔵生鮮肉 はエネルギー消費が少なく, 次に缶詰, 調理冷凍品, 冷 凍品の順にエネルギーを要することがわかる．缶詰は流 通・貯蔵にはエネルギー消費が少ないが, 包装材料（缶） および殺菌処理にエネルギーを要すること, 調理冷凍品 および冷凍品は凍結処理と凍結貯蔵に多くのエネルギー を要することがわかる.

農畜水産物生産 (一次生産及び輸入) から, 食品工業, 卸売・小売業, 外食産業を経て最終消費に至るまでに要 するエネルギーは, 我が国で消費する総エネルギー（直 接, 間接エネルギー）の約15\%であり，706兆 $\mathrm{kcal}$ とい われている(平成 2 年). 表13のよ5に食システムに要 する総エネルギー706兆 $\mathrm{kcal}$ のらち $32 \%$ が農畜水産物生

表12 冷蔵, 冷凍, 缶詰鷄肉の消費までに要するエネルギー

\begin{tabular}{|c|c|c|c|c|}
\hline 処理条件】品名 & 冷蔵鶏肉 & 冷凍鷄肉 & 調理冷凍鷄肉 & 缶詰䳕肉 \\
\hline 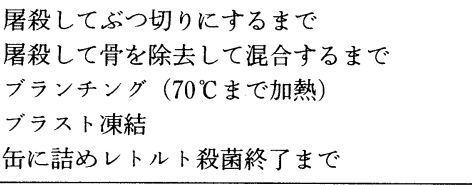 & $\begin{array}{l}990 \\
\cdots \\
\cdots \\
\cdots \\
\cdots\end{array}$ & $\begin{array}{c}990 \\
\cdots \\
\cdots \\
7,560 \\
\cdots\end{array}$ & $\begin{array}{c}\cdots \\
1,080 \\
800 \\
7,560 \\
\cdots\end{array}$ & $\begin{array}{c}\cdots \\
\cdots \\
\cdots \\
\cdots \\
5,680\end{array}$ \\
\hline $\begin{array}{l}\text { 鷄肉 } 1 \mathrm{~kg} \text { 当たりプラスチック容器や } \\
\text { トレーを } 15 \mathrm{~g} \text { 使用すると仮定すると } \\
\text { 包装用チューブ (厚さ } 30 \mu \mathrm{m} \text { ) } \\
\text { 鶏肉 } 1 \mathrm{~kg} \text { 当たりカートン箱を } 60 \mathrm{~g} \\
\text { 使用すると仮定すると } \\
\text { 缶材料 }\end{array}$ & $\begin{array}{c}750 \\
2,400 \\
\cdots\end{array}$ & $\begin{array}{c}750 \\
\cdots \\
2,400 \\
\cdots\end{array}$ & $\begin{array}{c}\cdots \\
60 \\
2,400 \\
\cdots\end{array}$ & $\begin{array}{c}\cdots \\
2,400 \\
10,500\end{array}$ \\
\hline $\begin{array}{l}3.5 \text { 週間の凍結貯蔵 } \\
\text { トラックによる輸送 }(200 \mathrm{~km}) \\
\text { 輸送中の冷却 }\left(0 \sim 5{ }^{\circ} \mathrm{C}\right) \\
\text { 輸送中の冷凍 }\left(-18^{\circ} \mathrm{C}\right)\end{array}$ & $\begin{array}{l}\cdots \\
600 \\
150 \\
\cdots\end{array}$ & $\begin{array}{c}5,150 \\
600 \\
\cdots \\
300\end{array}$ & $\begin{array}{c}5,150 \\
600 \\
\cdots \\
300\end{array}$ & $\begin{array}{c}\cdots \\
600 \\
\cdots \\
\cdots\end{array}$ \\
\hline $\begin{array}{l}\text { 小売販売店における保管（冷蔵） } \\
\text { 小売販売店における保管（冷凍） }\end{array}$ & $\begin{array}{c}300 \\
\cdots\end{array}$ & $\begin{array}{c}\cdots \\
600\end{array}$ & $\begin{array}{l}\cdots \\
600\end{array}$ & $\cdots$ \\
\hline $\begin{array}{l}\text { 家庭における眝蔵（冷蔵） } \\
\text { 家庭における䟺蔵（冷涷） } \\
\text { 家庭における調理 } \\
\text { 家庭における調理（ }(0 \sim 2000 \mathrm{~kJ} / \mathrm{kg} \text { の平均 })\end{array}$ & $\begin{array}{c}3,000 \\
\cdots \\
3,000 \\
\cdots\end{array}$ & $\begin{array}{l}6,000 \\
3,000 \\
\cdots\end{array}$ & $\begin{array}{c}8,000 \\
\cdots \\
1,000\end{array}$ & $\begin{array}{c}\cdots \\
\cdots \\
1,000\end{array}$ \\
\hline $\begin{array}{l}\text { ぶつ切にした鶏肉 } 1 \mathrm{~kg} \text { 当たりの全エネル } \\
\text { ギー使用量 }\end{array}$ & 11,190 & 29,350 & $\cdots$ & $\cdots$ \\
\hline $\begin{array}{l}\text { 可食部分 }(63 \%) 1 \mathrm{~kg} \text { 当たりの } \\
\text { 全エネルギー使用量 }\end{array}$ & 17,760 & 46,000 & 27,550 & 20,180 \\
\hline
\end{tabular}

BRYNJOLFSSON : U.S. Army Natic Laboratries(Food Division) 1978 
表13 食システムの燃料エネルギー利用, エネルギーコストの推移

\begin{tabular}{l|c|r|r|r|r|r|r}
\hline 項 目〉年 次 & 1960 年 & 1965 & 1970 & 1980 & 1985 & 1990 & 1995 \\
\hline 国内農漁業生産 & $55(32)$ & 100 & 147 & 180 & 159 & $141(86)$ & \\
万ち漁業 & $29(27)$ & 34 & 64 & 83 & 66 & $70(57)$ & \\
食料品輸入超過 & $11(6)$ & 30 & 41 & 60 & 65 & $82(46)$ & \\
\multicolumn{1}{c|}{ 計. } & $67(37)$ & 130 & 188 & 240 & 224 & $224(131)$ & \\
\hline 食品加工業 & $42(18)$ & 84 & 121 & 145 & 145 & $167(72)$ & \\
卸売, 小売業 & $9(5)$ & 16 & 43 & 53 & 88 & $59(31)$ & \\
飲食店 & $4(2)$ & 9 & 31 & 78 & 106 & $91(49)$ & \\
家庭 & $28(17)$ & 40 & 67 & 110 & 121 & $139(81)$ & \\
廃棄物処理 & $0(0)$ & 1 & 3 & 14 & 18 & $26(19)$ & \\
\hline 合計（兆kcal） & $149(79)$ & 281 & 453 & 640 & 701 & $706(383)$ & 738 \\
\hline 人口 & 93 百万人 & 98 & 104 & 117 & 121 & 124 & 126 \\
供給栄養熱量 & 80 兆 & 91 & 100 & 117 & 123 & 129 & 131 \\
エネルギーコスト & 1.86 & 3.08 & 4.54 & 5.48 & 5.71 & 5.49 & 5.61 \\
\hline
\end{tabular}

資料：久守 藤男「主要食料のエネルギーコスト」『食の科学』光琳 247 号 1998年 9 月

注 : 総務庁『産業連関表』, 農林水産省『食料需給表』を利用. 1960年, 1990年の括弧内は直 接エネルギー, 1995年の合計は久守の推計値. 供給栄養熱量には嗜好领料を含む.

【表中のエネルギーコストとは, 食品を掑取する迄に要したエネルギーを食品の持つエ ネルギー (栄養熱量) で除した数値のこと】

産, 食品工業が $24 \%$, 卸売・小売業が $8 \%$, 外食産業が $13 \%$, 家庭消費が $20 \%$ で, 残り $4 \%$ が廃棄に要するエネ ルギーである.これらの数值から見るならば，食品産業 はエネルギー多消費型産業とは言い得ない（なお，加工 食品の製造コストに占めるエネルギーは $4 \%$ 前後といわ れている).

しかし，産油国の事情および円の為替レートの変動か ら化石燃料価格の乱高下があり得ること, 化石燃料が有 限の資源であること，下記(12)に述べるよらに化石燃料の 燃焼に伴う排気ガスによる地球温暖化問題, 環境污染問 題および製造ュスト低減などを総合的に考慮するなら ば，食生活および食品産業において省エネルギー技術お よびシステムの開発が極めて重要な課題といえよう。

\section{(12) 地球環境, 生活環境の保全}

各産業活動の場および生活の場から排出される二酸化 炭素, メタン, フロン, 硫黄酸化物, 窒素酸化物などの 気体は, 地球温暖化, 酸性雨, オゾン層の破壊などの環 境破壊・污染に結び付き, 結果として地球環境およびわ れわれの生活環境に大さな影響を及ぼす.

飲食料の摂取に伴ら二酸化炭素の排出量を飲食費から みると，昭和 60 年では表 14 のごとく国民 1 人当たり約 $650 \mathrm{~kg}$ であった．その後の食料供給量および加工食品の 増加から，昨今では 1 人当たり $750 \sim 800 \mathrm{~kg}$ の排出と推 定される. 一方, 食料生産および食品加工の場から排出 される二酸化炭素の量は生産物および加工食品の出荷額 100万円あたり $1 \sim 5$ トンといわれている. 環境庁の調
表14 国民 1 人当たり飲食料費からみた二酸化炭素の排出量 (1985年)

\begin{tabular}{|c|c|}
\hline 食 品 群 名 & $\mathrm{CO}_{2}$ 排出量 $\left(\mathrm{CO}_{2} \mathrm{~kg} /\right.$ 人 $)$ \\
\hline 生鮮, 冷凍魚介 - 加工品 & 139.44 \\
\hline 畜肉, 鶏肉 · 卵 · 酪農品 & 68.37 \\
\hline 製穀·製粉· ‘ ん類 & 63.43 \\
\hline パン 菓 子 類 & 58.73 \\
\hline そ の 他 食 料 品 & 56.01 \\
\hline 野菜 . 果 実 & 51.07 \\
\hline 清 涼 飲 料 & 40.45 \\
\hline 調味 料 & 26.65 \\
\hline 冷 凍 調 理 食 品 & 7.10 \\
\hline 清酒・ビール・ウイスキー & 35.19 \\
\hline 夕 < । ב & 17.78 \\
\hline
\end{tabular}

飲食料及び㖶草の消費からの $\mathrm{CO}_{2}$ 排出量 653.74

吉岡 完治经：『イノベーション\&I-Oテク ニーク』4,(1),37〜46. (1993)

査によれば，我が国の二酸化炭素の総排出量は平成 8 年 では 3 億 3,680 万トン（炭素換算）であり，国民 1 人当 たり 2.68 トと発表している.これらの数值から類推す るならば，上記のエネルギー消費と同様に食生活からの 二酸化炭素排出量は比較的少ないといえよう.

二酸化炭素による地球温暖化が危惧されていることか ら, 国際的には, 第 3 回「気候変動枠組み条約」締約国 会議（1997年, 京都）において温室効果ガスの総排出量 を2012年には1990年に比べて平均 $5.2 \%$ （アメリカ $8 \%$, EU $7 \%$, 日本 $6 \%$ など）削減するなどの合意に達した. 各国とも排出量の削減の実行が急がれているが，具体的 
な削減は遅々としているようである，我が国においても 各産業に打いて二酸化炭素排出の削減に努力している が，経済団体連合会（経団連）の最近の調査によれば, 我が国の主要産業部門からの二酸化炭素排出量は, 1998 年度は1990年度に比較し $2.4 \%$ の減少であったが，現在 の削減対策を続けても2005年度には1990年度比で約 $3 \%$ の増加，対策を実施しない場合1990年度比で約10\%の増 加と予測している.（1990年度の我が国の二酸化炭素の 総排出量は炭素換算で3.07億トン, 産業部門での排出量 は1.71億トンである)

上記のほか，ゴミ焼却などによるダイオキシン污染が 約 20 年前から問題視されてきた。しかし，その具体的対 策はごく最近であり,ゴミ焼却施設の改善が進められ始 めた。

最近,クローズアップされ世界的対応を要する問題は, 内分泌攪乱物質いわゆる「環境ホルモン」である. 現時 点では各国で, これらの生物学的, 生化学的, 疫学的情 報収集と解析が進められている段階である.

\section{4.おわりに}

食品は理化学的にみて極めて複雑系の物質であり, か つ, 温度, 酸素, 紫外線, 微生物の影響を受けやすい不 安定な物質である. しかも, 日常の食品として消費者に 受け入れられるためには, 生理学的要素と心理学的要素 とが兼社備わっており, かつ, 消費者の嗜好（民族的, 地域的, 個人的）を満足し得るものでなくてはならない すなわち, 食品は「衣・食・住」のらち最も保守的性格
の強い物質である.

このような物質, すなわち原料食品を消費者の志向に マッチさせ, かつ省力的, 効率的, 省エネルギー的に流 通, 加工寸るために, 食品科学の基盤のらえに広範な領 域の科学技術の導入と総合とがなされ，豊かな食生活が 支えられているのである.

本稿では, 今日の「豊かで, 健全な食生活」を21世紀 に結び付けるべく, 食生活をとりまく今日的, 将来的な 話題を要約し問題点を指摘し, 二, 三の考察を試みた. 本稿が今後の食生活, 食品産業を思考する際の参考にな れば幸甚である.

\section{参考文献}

1）(社)食品流通システム協会編集：食品流通ハンドブック 恒星社厚生閣 (1989)

2）吉岡完治ら：環太平洋産業連環学会誌「イノベーショ ンI-O テクニーク」Vol.3〜4（1992～1993）

3）木村 進：「食品産業の現状と技術的課題」食の科 学・通巻200号 光琳 (1994)

4）木村 進：「食生活・食品産業をめぐる話題」食の科 学・通巻244号 光琳 (1998)

5）久守藤男：「主要食料品のエネルギーコスト」食の科 学・通巻247号 光琳 (1998)

6）農水省食品流通審議会食品環境専門委員会「食品産業 の有機性廃棄物のリサイクルの推進方向」(1998)

7）(財)食品産業センター：「内分泌攪乱物質をめぐる状況 について」『明日の食品産業』通巻289号（1998）

8）(狽食品産業センター：「食品産業統計年報」平成11年 度版（1999） 